\title{
"PAY FOR DELAY": LEGITIMATE CONDUCT TO DEFEND VALID PATENT RIGHTS OR ANTICOMPETITIVE BEHAVIOUR?
}

\author{
Molly Anning*
}

Originator and generic drug manufacturers frequently settle patent litigation on terms that include a payment to the generic manufacturer in return for the generic to delay entry into the market. These reverse-payment settlements extend the originator's market exclusivity and can amount to anticompetitive divisions of the market. Proponents of such settlements emphasise the reversepayment as a legitimate business response to the risks associated with litigation. While reversepayment settlements have raised considerable debate in the pharmaceutical field in both the United States and the European Union, competition authorities in New Zealand are yet to address this issue. Against this background, this article seeks to analyse the compatibility of such settlements with New Zealand competition law, in particular with ss 27 and 36 of the Commerce Act 1986. Given the diversity of such agreements, it is unclear whether New Zealand competition law is adequate to curtail reverse-payment settlements.

\section{INTRODUCTION}

In the pharmaceutical industry, originators are manufacturers which develop new pharmaceutical products. Generics manufacture bioequivalent versions of drugs which an originator initially developed. In researching and developing new medicines, originators obtain a range of patents to protect these medicines against generic competition. Competing generic companies scout opportunities to challenge the validity of patents or may enter a market at the risk of infringing the originator's exclusive rights. These competing incentives often culminate in patent litigation. Reversepayment settlements are a form of resolution attractive to risk-averse parties. The legality of such settlements has made it difficult for competition lawyers to advise and such a settlement has yet to come before a New Zealand court.

* Submitted as part of the LLB (Hons) programme at Victoria University of Wellington. 
The impetus for this article derives from a concern that some powerful pharmaceutical companies are hiding behind patent protection to preserve monopoly profits and delay the entry of generic competitors. Where an anticompetitive agenda exists, consumers are impacted through increased public expenditure on medicines and reduced consumer choice of alternative medicines. ${ }^{1}$ These behind-the-curtain power alliances between a bully originator and a greedy generic hedging its bets with litigation must be extinguished.

The complexity of the pharmaceutical market and the interplay of intellectual property and competition law form the themes for this article. First, an introduction to the New Zealand pharmaceutical industry, intellectual property scheme and the effects of generic entry is given to set the scene for the following analysis. Second, this article will discuss how ss 27 and 36 of the Commerce Act 1986 apply to reverse-payment settlements. Drawing upon decisions from the United States, the European Union and Australia, this article assesses whether the current law adequately curtails such unilateral conduct. It challenges conventional interpretations of these provisions and encourages a new approach in light of unique pharmaceutical industry characteristics, based on the following conclusions:

(1) The current approach to market definition is problematic in the pharmaceutical industry.

(2) To assess the potential net effect of such settlements on market competition, an ex ante inquiry into patent validity/infringement is crucial.

(3) Section 27 will be violated only where the challenged agreement contains restrictions on competition that exceed the exclusionary potential of the patent and the likelihood of originator success in the patent dispute is low.

(4) The counterfactual test, under s 36, continues to cause problems when analysing the behaviour of originator pharmaceutical companies.

This article looks at the application of the law to claims where there is an anticompetitive purpose and/or effect. It does not consider legitimate challenges, weak patents or genuine patent infringement. This article focuses on the pharmaceutical sector. Its conclusions will also apply to other industries.

1 OECD Secretariat Directorate for Financial and Enterprise Affairs Competition Committee: Executive Summary of the Discussion on Competition and Generic Pharmaceuticals (DEP/CAF/COMP/M(2014)2/ ANN6/FINAL, 10 February 2015) at 2. 


\section{THE PHARMACEUTICAL SECTOR: INTELLECTUAL PROPERTY AND GENERIC ENTRY}

\section{A Prescription Medicine Supply Chain}

New Zealand's pharmaceutical supply chain is complex. It includes manufacturers (originators and generics), the Pharmaceutical Management Agency (PHARMAC), District Health Boards, wholesalers, Community Pharmacies and consumers: ${ }^{2}$

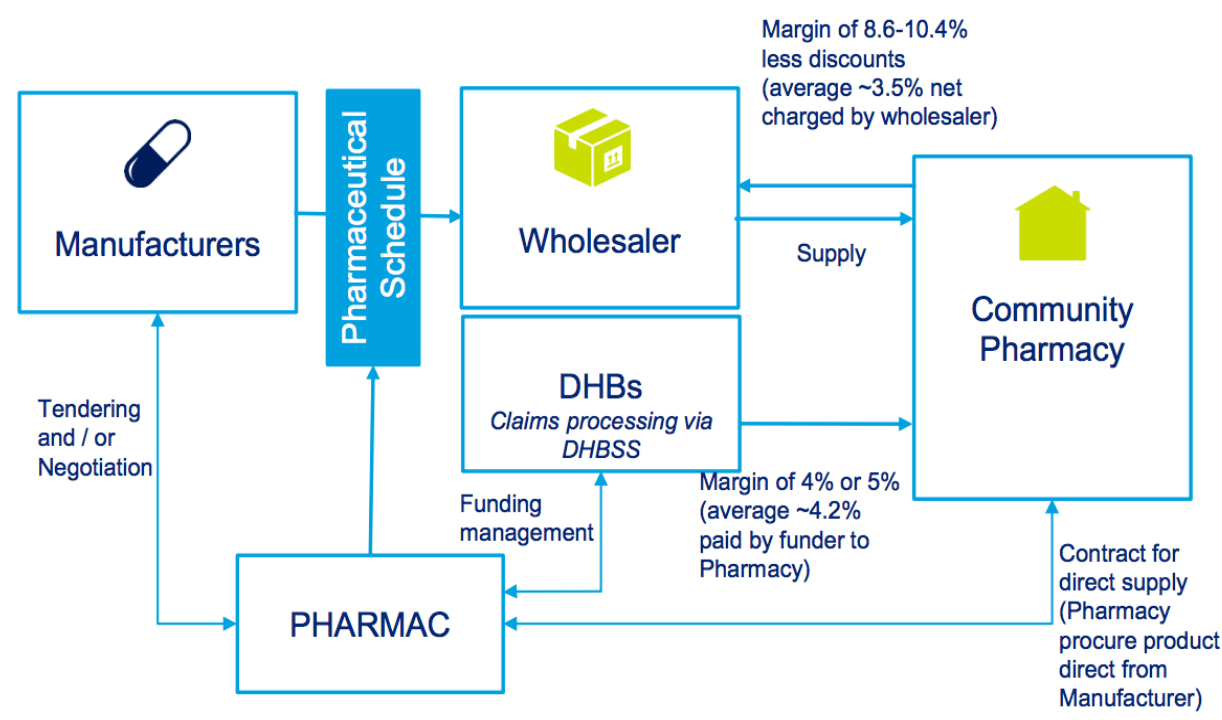

The New Zealand Medicines and Medical Safety Authority approves and registers pharmaceuticals. ${ }^{3}$ Once the Ministry of Health sets a budget, PHARMAC manages pharmaceutical spending. ${ }^{4}$ Pharmaceuticals which meet eligibility criteria and receive subsidised funding from PHARMAC become listed on the Pharmaceutical Schedule. ${ }^{5}$ PHARMAC's role in New Zealand is distinct. Overseas, wholesalers typically engage directly with manufacturers. ${ }^{6}$

\section{B Intellectual Property Protection}

The pharmaceutical industry is innovative and high-technology, heavily reliant upon the protections patents afford. Innovation by originators is crucial to developing new medicines against

2 Deloitte Environmental Scan Regarding Drug Margins (January 2015) at 8.

3 At 8 .

4 At 8 .

5 At 8 .

6 At 13. 
different illnesses. Developing a new drug takes an average of 12 years, ${ }^{7}$ and it can cost over NZD 3.6 billion. ${ }^{8}$ The cost is typically $15-18$ per cent of sales revenue. ${ }^{9}$ Patent protection guarantees some return on the originator's research and development investment.

In New Zealand, a patent has a life of 20 years from the date of the patent application. ${ }^{10}$ Unlike Australia and the United States, New Zealand does not offer any patent term extension. ${ }^{11}$ The process to obtain Medsafe's approval for marketing a pharmaceutical is lengthy and can reduce the "effective patent term" below the 20 years in the Patents Act 2013. ${ }^{12}$ Pharmaceutical companies argue this reduces their ability to recoup their investment in developing pharmaceuticals and minimises any incentive to continue doing so. ${ }^{13}$

A patent creates a legal monopoly as a source of exclusive rights to make, use, sell or otherwise deal in the invention in New Zealand. ${ }^{14}$ This does not conflict with competition law, as the object of both is to promote innovation and competition. ${ }^{15} \mathrm{~A}$ pharmaceutical patent provides a sufficient degree of protection to ensure the development of new drugs, without making it difficult for competitors to enter the market. ${ }^{16}$ The promise of monopoly rents creates "in-market" competition between originators to bring the first (or most effective) treatments to the market. ${ }^{17}$ An originator patents a

7 Medicines New Zealand "Examining medicines: Generic versus biologic - Patent term versus Data Protection" <www.medicinesnz.co.nz>.

8 International Federation of Pharmaceutical Manufacturers \& Associations "The Pharmaceutical Industry and Global Health: Facts and Figures 2017" (2017) <www.ifpma.org> at 8.

9 Researched Medicines Industry Association of New Zealand Inc "Submission to the Commerce Committee on the Patents Bill" at [3].

10 Patents Act 2013, s 20.

11 Tim Jackson "Extension of Patent Term in New Zealand" (17 May 2016) Baldwins Intellectual Property \& Patent Attorneys <www.baldwins.com>. The Trans-Pacific Partnership Agreement Amendment Act 2016 provides a 20 -year patent term extension, although this legislation is not yet in force.

12 Ministry of Business, Innovation and Employment Regulatory Impact Statement: Analysis of Options Relating to Implementation of Certain Intellectual Property Obligations under the Trans-Pacific Partnership Agreement (April 2016) at [4].

13 At [45].

14 James F Ponsoldt and W Hennen Ehrenclou "The Antitrust Legality of Pharmaceutical Patent Litigation Settlements" [2006] University of Illinois Journal of Law, Technology \& Policy 37 at 38.

15 OECD Directorate for Financial and Enterprise Affairs Competition Committee: Generic Pharmaceuticals - Note by the Delegation of India (DAF/COMP/WD(2014)72, 28 May 2014) at 3.

16 At 3 .

17 Colette Downie "Strategically Deterring Generic Entry Ahead of Patent Expiry: A Competition Law Antidote? Assessing Australian Pharmaceutical Antirust Enforcement after ACCC v Pfizer" (2017) 45 ABLR 75 at 82 . 
particular active ingredient or production process. It is not until the patent expires that other manufacturers can make generic medicines using the same active ingredient or production process.

While patentees can defend valid patent rights, the validity of these rights can be a trigger for litigation. Where settlements eventuate, particular clauses may attract competition law scrutiny, especially where the settlement delays or prevents a generic entering into the market.

\section{Generic Entry}

The intricacy of the pharmaceutical industry is accompanied by an event with drastic implications for an originator: generic entry. Generics can enter a drug market in only a few circumstances:

(1) on expiry of the originator drug's patent term; ${ }^{18}$

(2) with a licence from the originator patentee;

(3) if an originator's patent is invalid or not infringed; ${ }^{19}$ or

(4) at the risk of infringing a patent.

In New Zealand, manufacturers competitively tender for exclusive rights to supply pharmacies with generic medicines. ${ }^{20}$ This process includes almost half of subsidised pharmaceuticals in New Zealand (by volume), which represents 20 per cent of total pharmaceuticals costs and generates around NZD 40-60 million in savings per annum. ${ }^{21}$ PHARMAC has developed one of the lowest pharmaceutical cost structures in the developed world. ${ }^{22}$ The strategy has been to "wait out" patents of new and innovative medicines and fund generic substitutes. ${ }^{23}$ This model has eroded intellectual property rights of originators and reduced incentives to innovate. ${ }^{24}$ This regulatory climate incentivises originators to turn to their own devices in protecting their investment in research and development and encourages generics to either challenge patent validity or enter the market at risk of infringing a patent.

18 At 83 .

19 Rebecca Eisenberg and Daniel Crane "Patent Punting: How FDA and Antitrust Courts Undermine the HatchWaxman Act to Avoid Dealing with Patents" (2015) 21 MTTLR 197 at 229.

20 Deloitte, above $\mathrm{n} 2$, at 8.

21 At 8 .

22 Researched Medicines Industry Association of New Zealand Inc, above n 9, at [3].

23 At [3].

24 For drugs developed by overseas companies, New Zealand will likely comprise a very small part of their total target market. Therefore, the New Zealand system is unlikely to have a major chilling effect on their investment in research and development. 
Entry of a generic enhances competition by driving prices down and providing choice between prescription medicine brands to the benefit of consumers and governments. ${ }^{25}$ On a generic's entry price falls on average 85 per cent below the brand price before generic entry, ${ }^{26}$ impacting the originator's market share and profits. ${ }^{27}$ For example, a 100-pill bottle of the antibiotic ciprofloxacin that cost USD 322 fell after generic entry to USD 14, a 95 per cent difference in price. ${ }^{28}$ This immediate decline in revenue after patent expiration is called a "patent cliff". ${ }^{29}$ This incentivises originator's to prevent or delay generic entry to defend revenue and maximise profits. ${ }^{30}$

Originators have invested a considerable amount of effort in developing elaborate strategies for dealing with and delaying the consequences of generic entry. New Zealand patent law does not allow patentees to extend their patent. ${ }^{31}$ Rather than relying on the intellectual property scheme to preserve or extend exclusive rights and delay generic entry, originators could be more inclined to pursue anticompetitive tactics.

\section{REVERSE-PAYMENT SETTLEMENTS}

Generics may find it profitable to challenge the patentee's exclusive rights before patent expiration, by either entering the market or suing the patent holder challenging the patent's validity. ${ }^{32}$ Following publication of a patent, there is a three-month period where interested parties can object to the grant of the application. ${ }^{33}$ Proceedings occur in the High Court when challenging a patent existing for longer than a year. ${ }^{34}$ Comparatively, a generic entering the market prior to patent expiry may face an infringement action from the patentee. Conflicting incentives of originator and generic companies

25 Hans Lofgren "Generic Medicines in Australia: Business Dynamics and Recent Policy Reform" (2009) 2 SMR 24.

26 Michael A Carrier "Pharmaceutical Antitrust Law in the United States" in Giovanni Pitruzella and Gabriella Muscolo (eds) Competition and Patent Law in the Pharmaceutical Sector: An International Perspective (Wolters Kluwer, Alphen aan den Rijn, 2016) 477 at 479.

27 Lofgren, above n 25, at 24.

28 Re Ciprofloxacin Hydrochloride Antitrust Litigation 363 F Supp 2d 514 (ED NY 2005) as cited in Carrier, above $\mathrm{n} 26$, at 479 .

29 Chie Hoon Song and Jeung-Whan Han "Patent cliff and strategic switch: exploring strategic design possibilities in the pharmaceutical industry" (2016) 5 Springerplus 692 at 692.

30 OECD Secretariat, above n 1, at 4.

31 Jackson, above n 11.

32 Zhenghui Wang "Reanalyzing Reverse-Payment Settlements: A Solution to the Patentee's Dilemma" (2014) 99 Cornell L Rev 1227 at 1228.

33 Patent Regulations 2014, reg 93.

34 James \& Wells "Challenging a patent application or granted patent" <www.jaws.co.nz>. 
increase the likelihood of litigation and therefore settlements between the parties. These settlements often involve a reverse-payment.

Reverse-payment settlements occur when a generic company enters, or threatens to enter, the market before the expiry of the patent. To avoid early competition, patent invalidation or costly and lengthy litigation, the originator and generic company reach a settlement. ${ }^{35}$ The originator pays a generic to delay the launch of its generic version. ${ }^{36}$

These entry restrictions may look like, but are not limited to, the following: ${ }^{37}$

(a) a generic company delays entry until the patent's expiry or a negotiated entry date;

(b) the generic company agrees not to challenge the validity of the originator company's patent;

(c) a licence from an originator company limits the generic firm's ability to market its own product; and/or

(d) a distribution or supply agreement between the originator and generic limits the latter's ability to market its product.

Although courts typically encourage settlements, the legality of those involving reverse-payments is concerning. If the generic company would have entered the market, but for the agreement, a payment by a market incumbent to restrict a potential competitor looks like an obvious collusion to circumvent competition. ${ }^{38}$ This is particularly concerning when the originator and generic company benefit from the agreement at the expense of the consumer. The originator shares patent revenues with the generic challenger, despite delayed generic entry. ${ }^{39} \mathrm{~A}$ further concern is whether the infringement or patent invalidity claim has merit or whether such settlements are a "thin camouflage" for improper collusion to delay competition. ${ }^{40}$

Reverse-payment settlements have received extensive academic and judicial consideration in the United States and the European Union. The scant evidence of their existence in New Zealand likely arises from their inherently confidential nature, which increases the difficulty for the Commerce Commission in detecting "suspect transactions". ${ }^{41}$ Along with New Zealand being much smaller and

35 Robin Feldman and Evan Frondorf "Drug Wars: A New Generation of Generic Pharmaceutical Delay" (2016) 53 Harv J on Legis 499 at 510.

36 Ponsoldt and Ehrenclou, above n 14, at 37.

37 Ginevra Bruzzone and Sara Capozzi "The Procompetitive and Anticompetitive Impact of Patent Settlements" in Giovanni Pitruzella and Gabriella Muscolo (eds) Competition and Patent Law in the Pharmaceutical Sector: An International Perspective (Wolters Kluwer, Alphen aan den Rijn, 2016) 15 at 20.

38 Eisenberg and Crane, above n 19, at 229.

39 OECD Secretariat, above $\mathrm{n} 1$, at 6

40 Downie, above $\mathrm{n} 17$, at 105.

41 At 105 
with far less litigation than the United States, there is also less scope for reverse-payment settlements due to the lack of patent extension provisions in New Zealand.

\section{A Where Things Get Complicated}

Competition law's role and the standard of review is controversial in the face of uncertainty. Two scenarios illustrate this.

\section{Scenario A}

This scenario assumes the patent's validity and entry of a generic would infringe an originator's intellectual property rights. Any agreement excluding the generic until patent expiry would be consistent with the originator's exclusive rights. ${ }^{42}$ This does not restrict competition, as a generic infringing upon an intellectual property right cannot be a competitor of the originator patentee.

\section{Scenario B}

This scenario concerns agreements aimed to delay products from entering the market which fall outside the scope of the patent and are not protected by the originator's intellectual property rights. Here, conflict exists between intellectual property rights and competition law. Such an agreement will restrict competition.

The closest New Zealand came to making a reverse-payment settlement inquiry was the Commission's Metal Roof Flashings Investigation Report in $2015 .{ }^{43}$ The Commission warned Consolidated Alloys about an anticompetitive clause in an agreement to settle intellectual property litigation. Although the Commission has not received any complaint in relation to reverse-payment agreements, its decision to take enforcement against Consolidated Alloys could signal a willingness to take cases where intellectual property and competition law intersect. ${ }^{44}$

\section{B Anticompetitive Effects of Reverse-Payment Settlements}

There is an argument that reverse-payment settlements are objectively anticompetitive because originators are permitted to exclude potential rivals. ${ }^{45}$ Harm to consumers arises because if litigation occurred, a court could hold the patent was invalid or not infringed. This would allow a generic to enter, increasing competition and lowering prices. ${ }^{46}$ PHARMAC subsidises prescribed medicines,

42 Eisenberg and Crane, above n 19, at 229.

43 Commerce Commission Metal Roof Flashings (Investigation Report, project no 11.02/14923, 5 October 2015) at 21.

44 Elisha Kemp, Troy Pilkington and Sarah Keene "When rights go wrong: Commerce Commission issues warning to Consolidated Alloys" (9 October 2015) Russell McVeagh <www.russellmcveagh.com>.

45 Wang, above n 32 , at 1241 .

46 Ponsoldt and Ehrenclou, above n 14, at 55. 
therefore weighing on the public health budget. The prospect of cheaper prices for consumers is lost as a product of avoiding litigation. ${ }^{47}$ Opponents of reverse-payment settlements equate the "reversed" flow of the settlement payments with conspiracy to divide the market. ${ }^{48}$ A reverse-payment may be economically rational where the net present value of settlement exceeds that of litigation for both parties. ${ }^{49}$ Industry-specific regulation undermines patent policy in the context of industry-specific reverse-payment settlements. ${ }^{50}$ Regulatory protection already benefits originators; the Commission should scrutinise synthetic legal devices which extend protection and the brand should bear the burden to rebut that presumption. ${ }^{51}$ The inelasticity of the pharmaceutical drug market, offering few substitutes to drugs needed to live and stay healthy, further supports stricter scrutiny of such settlements. 52

\section{Legitimate Business Conduct}

To comprehend the dynamics of reverse-payment settlements, understanding the competing risks both the originator and generic company bear in litigation is crucial. These settlements are attractive to originators who risk losing a patent infringement action and a new entrant disrupting their patent monopoly. ${ }^{53}$ Risk-averse parties are likely to settle. ${ }^{54}$ This is not necessarily because the patent case is weak, it is also possible the patentee considers the patent so valuable it is willing to pay a substantial premium to avoid even a slight chance of invalidity. ${ }^{55}$ Settlements avoid litigation costs and diversion of other internal resources. ${ }^{56}$ Determining patent validity is costly and lengthy, particularly with pharmaceuticals. ${ }^{57}$ The ability to settle is equated with insurance to foster innovation resulting in

47 C Scott Hemphill "Paying for Delay: Pharmaceutical Patent Settlement as a Regulatory Design Problem" (2006) 81 NYU L Rev 1553 at 1557.

48 Anjan Chatterji and Xiang Yu "Why Brand Pharmaceutical Companies Choose to Pay Generics in Settling Patent Disputes: A Systematic Evaluation of Asymmetric Risks in Litigation" (2011) 10 Nw J Tech \& Intell Prop 19 at 24 .

49 At 24.

50 Hemphill, above n 47, at 1561-1567.

51 At 1561 and 1615 .

52 Ponsoldt and Ehrenclou, above n 14, at 55.

53 At 55 .

54 Eisenberg and Crane, above n 19, at 229.

55 At 238

56 Keith M Drake, Martha A Starr and Thomas McGuire "Do 'Reverse-payment' Settlements of Brand-Generic Patent Disputes in the Pharmaceutical Industry Constitute an Anticompetitive Pay for Delay?" (Working Paper 20292, National Bureau of Economic Research, July 2014).

57 Chatterji and Yu, above $\mathrm{n} 48$, at 32 . 
procompetitive effects in the long term. ${ }^{58}$ Without this insurance, risk-averse originators will be reluctant to invest capital into research and development. ${ }^{59}$ There appears to be a trade-off between preserving consumer prices for existing products and stimulating research and production of future products. ${ }^{60}$ Additionally, empirical data suggests the impact of reverse-payment settlements can sometimes be minimal or neutral. ${ }^{61}$ A reverse-payment settlement should be illegal only when its anticompetitive effects outweigh its procompetitive benefits. Some scholars argue risk management should not be an admissible justification because allowing reverse-payments that foster such riskaverse decisions inefficiently lowers shareholder returns and incentives to invest in innovation. ${ }^{62}$

Evaluation of the economic benefit suggests both parties usually prefer settlement with reversepayment over litigation. ${ }^{63}$ In assessing United States courts of appeal cases, Chatterji and Yu find reverse-payment settlements are consistent with risk aversion and no collusion is necessary for a brand to make a rational decision to pay the generic. ${ }^{64}$

\section{NEW ZEALAND: RESTRICTIVE TRADE PRACTICES AND EXEMPTIONS}

Part 2 of the Commerce Act prohibits restrictive trade practices. The Act's purpose is to promote competition in markets for the long-term benefit of consumers. ${ }^{65}$ Section 27 proscribes the provision of a contract, arrangement or understanding if it has the purpose or effect or likely effect of substantially lessening competition in a market. Section 36 prohibits a person with a substantial degree of power in a market from taking advantage of that power for the purposes of restricting the entry of a person into that or any other market, preventing or deterring a person from engaging in competitive conduct in that market or eliminating a person from that or any other market. Sections 27 and 36 are key instruments for testing the competition boundaries of reverse-payment settlements. ${ }^{66}$

58 James Langenfeld and Wenqing Li "Intellectual Property and Agreements to Settle Patent Disputes: The Case of Settlement Agreements with Payments from Branded to Generic Drug Manufacturers" (2003) 70 ALJ 777 at 808 .

59 Chatterji and Yu, above $\mathrm{n} 48$, at 32.

60 Langenfeld and $\mathrm{Li}$, above $\mathrm{n} 58$, at 778.

61 Henry Butler and Jeffrey Jarosch "Policy Reversal on Reverse-payments: Why Court Should Not Follow the New DOH Position on Reverse-Payment Settlements of Pharmaceutical Patent Litigation" (2010) 96 Iowa L Rev 57 at $112-113$.

62 Thomas G McGuire and others "Resolving Reverse-Payment Settlements with the Smoking Gun of Stock Price Movement" (2016) 81 Iowa L Rev 1581 at 1586.

63 Chatterji and Yu, above n 48, at 19.

64 At 20.

65 Commerce Act 1986, s 1A.

66 In August 2017, s 30 was "expanded" to explicitly prohibit capacity withholding and market sharing. A reverse-payment settlement is an agreement not to enter a market/withhold capacity. In practice, the 
The Act has two intellectual property exemptions. Section 45 establishes a limited safe harbour for certain licensing practices where the intellectual property holder does not have a substantial degree of market power. There is no case law on this exemption and the Ministry of Business Innovation and Employment did not consider the matter in its Targeted Review of the Commerce Act $1986 .{ }^{67}$ Sumpter, Hamlin and Mellsop suggest this is likely driven by the common belief among practitioners and the Commission that an intellectual property licence by itself is unlikely to hinder competition rules. ${ }^{68}$ Section 36(3) provides an exemption from the misuse of market power provision only for conduct seeking to enforce a statutory intellectual property right. It remains unclear whether the protection offered by s 36(3) is as broad as it appears. The only decision mentioning the provision is Telecom Corporation of New Zealand Ltd v Clear Communications Ltd in a strike out application. ${ }^{69}$ The High Court interpreted s 36(3) to allow an intellectual property right holder to file proceedings and enforce its intellectual property rights. This section is unlikely to assist parties who have entered a reversepayment settlement.

The Commerce Act is based upon Australia's Trade Practices Act 1974 (now called the Consumer and Competition Act 2010). ${ }^{70}$ It is appropriate to draw upon Australian commentary and judicial decisions when assessing how ss 27 and 36 apply to reverse-payment settlements in New Zealand.

\section{A The Market}

It is important to define the parameters of the market in which the defendant product competes. As Burchett $\mathbf{J}$ in News Ltd v Australian Rugby Football League Ltd observed "the identification of too narrow or too broad a market will completely distort the picture gained of the competitive forces at work". ${ }^{71}$

The Act defines a market as a market in New Zealand for goods and services as well as other goods and services that are substitutable as a matter of fact and commercial common sense. ${ }^{72}$ The leading judgment from the Trade Practices Commission in Re Queensland Co-Op Milling Assoc Ltd and Defiance Holdings Ltd defined a market as "the area of close competition between firms". ${ }^{73} \mathrm{New}$

Commission takes far more cases under s 30, because it does not have to prove "substantial lessening of competition". The Commission would likely take any reverse-payment settlement action under this section.

67 Ministry of Business, Innovation and Employment Targeted Review of the Commerce Act 1986 (2015).

68 Matt Sumpter, Ben Hamlin and James Mellsop New Zealand Competition Law and Policy (Wolter Kluwer, Auckland, 2010) at 1208.

69 At 1208; and Telecom Corporation of New Zealand Ltd v Clear Communications Ltd [1992] 3 NZLR 247 (HC).

70 Lindsay Hampton and Paul Scott Guide to Competition Law (LexisNexis, Wellington, 2013) at 75.

71 News Ltd v Australian Rugby Football League Ltd [1996] FCA 1256, (1996) 135 ALR 33 at [83].

72 Commerce Act, s 3(1A)

73 Re Queensland Co-Op Milling Assoc Ltd and Defiance Holdings Ltd (1976) 8 ALR 481 (TPC) at 517. 
Zealand courts have adopted the "SSNIP" (small, yet significant non-transitory increase in price) test. ${ }^{74}$ The United States Department of Justice pioneered the test in the 1982 Merger Guidelines. It has become a worldwide standard for defining markets and is in the Commerce Commission's Mergers and Acquisitions Guidelines.

The test defines the relevant market as the smallest set of products or services within which a hypothetical profit-maximising sole supplier of a good or service would find it profitable to increase prices by 5-10 per cent from a competitive price level for at least a year (avoiding cellophane fallacy). ${ }^{75}$ The test is repeated until a market is found where it would be profitable to impose a SSNIP. ${ }^{76}$ Delineation of the five dimensions of a market involve separate applications of the SSNIP test. These dimensions are: product/service, geographic, functional, temporal and customer. ${ }^{77}$ There may be potential competitors who can enter the market quickly in response to a SSNIP, if so, there will be supply-side substitution. ${ }^{78}$ Supply-side substitution or new entry seems an irrelevant consideration in the pharmaceutical context, given the originator (and patent holder) is likely to be the only supplier in New Zealand.

The SSNIP test is unsuitable in a monopolisation context because the test assumes existing competitive prices. ${ }^{79}$ A monopolist might have set its prices at such a high level that further price increase above current prices would not be profitable. ${ }^{80}$ This is commonly referred to as the "cellophane fallacy". ${ }^{81}$ Applying the SSNIP test here would lead to too wide a market definition and a likely finding that the firm does not possess substantial market power. ${ }^{82}$

The pharmaceutical industry's unique nature challenges the applicability of the SSNIP test in New Zealand. Many assumptions underlying the SSNIP test do not apply. First, an originator preserves a legal monopoly until patent expiration. Second, prices in New Zealand drugs markets are subject to regulation by PHARMAC with monopsony power. Drug companies cannot set prices or raise them

74 New Zealand Bus Ltd v Commerce Commission [2007] NZCA 502, [2008] 3 NZLR 433 at [202].

75 Commerce Commission Mergers and Acquisitions Guidelines (July 2013) at [3.18].

76 At [3.18].

77 Hampton and Scott, above n 70, at 70-73.

78 At 64.

79 At 73.

80 At 74.

81 United States v El du Pont de Nemours \& Co 351 US 377 (1956).

82 Massimo Motta Competition Policy: Theory and Practice (Cambridge University Press, Cambridge, 2004) at 105 . 
over time. ${ }^{83}$ Third, in the case of prescription drugs, consumer preferences do not determine substitutability. Since the doctor is the ultimate decision maker, there is very limited price sensitivity. ${ }^{84}$ Applying the SSNIP test in the pharmaceutical context is unlikely to provide much insight into competition dynamics of the relevant market.

In Australian Competition and Consumer Commission v Pfizer Australia Pty Ltd, the High Court of Australia accepted the Australian Competition and Consumer Commission's characterisation of the relevant market as the "Australia-wide 'market' for the supply of atorvastatin to, and acquisition of atorvastatin by, community pharmacies. ${ }^{185}$ The Court accepted that although generic manufacturers often sell "ranges" of products, atorvastatin was sold as a separate pharmaceutical product for which there was no substitute. ${ }^{86}$ Re Aggrenox Antitrust Litigation filled the gap left by the Supreme Court Federal Trade Commission v Actavis Inc decision in defining the market. ${ }^{87}$ The Court determined the relevant market "by the nature of the challenged agreement", and concluded the only relevant market was that for Aggrenox and its generic equivalent and did not include therapeutic competitors. ${ }^{88}$ This narrow approach to market definition will provide an indication of the originator's market power. This is consistent with the High Court's observation in Telecom Corporation of New Zealand Ltd $v$ Commerce Commission that "a mechanical reliance upon substitution criteria in a contextual vacuum is not sufficient" ${ }^{89}$ Market definition is a tool for competition analysis, not an end in itself. ${ }^{90}$

In light of the above, a market definition assessment when considering pharmaceutical entry should include the following three aspects. First, a court should consider evidence of therapeutic substitutes to restrict the "choice set" to the compounds doctors regard as substitutable for treating a specific condition. ${ }^{91}$ Second, a court needs evidence of prescribing patterns among doctors to provide realistic indications of the functional substitutability of two drugs prescribed for the same condition. Third, a court requires evidence of the impact of different competitive strategies on sales of a specific

83 Charles River Associates "Market Definition in the Pharmaceutical Sector" (November 2006) $<$ http://ecp.crai.com>.

84 United Nations Conference on Trade and Development Secretariat The role of competition in the pharmaceutical sector and its benefits for consumers (TD/RBP/CONF.8/3, 2015) at 5.

85 Australian Competition and Consumer Commission v Pfizer Australia Pty Ltd [2015] FCA 113, (2015) 323 ALR 429 at [251]

86 At [272].

87 Re Aggrenox Antitrust Litigation 199 F Supp 3d 662 (D Conn 2016); and Federal Trade Commission v Actavis Inc 570 US 133/2223 (2013).

88 Re Aggrenox Antitrust Litigation, above n 87, at 669.

89 Telecom Corporation of New Zealand Ltd v Commerce Commission (1991) 4 TCLR 473 (HC) at 499.

90 Frank P Maier-Rigaud and Ulrich Schwalbe Market Definition (OECD, DAF/COMP(2012)13/REV1, 21 September 2012).

91 Charles River Associates, above n 83, at 1. 
product to understand the patterns of substitution among different prescription drugs. ${ }^{92}$ This methodology of defining pharmaceutical sector markets takes into account the industry's unique features.

\section{B Section 27}

Section 27 prohibits a firm from entering into or giving effect to a provision of an agreement that has the purpose or effect or likely effect of substantially lessening competition in a market. The limbs of s 27 are disjunctive and capture conduct the others relevant sections will not. ${ }^{93}$ First, a court will encounter the difficulty of defining the relevant market. This is discussed above. Second, depending on how a plaintiff has put their case, a court will undertake an analysis under the relevant limb or limbs of s 27 .

\section{Purpose}

The purpose inquiry under s 27 requires an objective assessment ${ }^{94}$ of the substantial purpose of the provision. ${ }^{95}$ Evidence of subjective purpose may inform the analysis in circumstances where it is "borderline as to whether there might be an anti-competitive effect". 96 If it is obvious that purpose is unascertainable on implementation of the provision, assessed objectively, the provision cannot have had that purpose. ${ }^{97}$

Reverse-payment settlements in the pharmaceutical industry, objectively, have an anticompetitive purpose. The majority in Actavis state "[i]f the basic reason is a desire to maintain and to share patentgenerated monopoly profits, then, in absence of some other justification, the anti-trust laws are likely to forbid the arrangement." 98 Despite being a reality of the patent system, which motivates and rewards innovators for new inventions, the exclusion of competitors to maintain patent-generated monopoly profits carries with it an anticompetitive purpose. Risk management justifications may also reveal an intention to substantially lessen competition. Settlements typically insure against the possibility of an adverse outcome, which in the context of patent litigation is increased competition

92 At 2 .

93 Paul Scott "The Purpose of Substantially Lessening Competition: The Divergence Between New Zealand and Australian Law" (2011) 19 Wai L Rev 168 at 172.

94 New Zealand authorities differ on the approach to purpose under s 27. The majority judgment of Glazebrook J confirmed an objective assessment: ANZCO Foods Waitara Ltd v AFFCO New Zealand Ltd [2006] 3 NZLR $351(\mathrm{CA})$.

95 Commerce Act, s 2(5).

96 ANZCO, above n 94, at [261].

97 At [257].

98 Actavis, above n 87, at 2236-2237. 
for the originator. ${ }^{99}$ Where parties are aware of the likelihood of success of patent litigation, this suggests either a genuine settlement to avoid litigation risks or collusion to avoid competition. Any documents expressing concerns regarding competition law compliance in relation to "deals" being done with generic producers is another warning sign. ${ }^{100}$

Evidentiary difficulties in substantiating an inference purpose case indicate careful documentation by originators of the procompetitive and risk management reasoning behind the reverse-payment settlement. ${ }^{101}$ These difficulties, coupled with evidence from credible senior decision makers, can effectively displace prejudicial inferences as to the substantial purpose behind the reverse-payment settlement. ${ }^{102}$ Pfizer demonstrated this. ${ }^{103}$ These assessments require reference to the parties' contemporaneous internal documents. This highlights the need for companies to ensure their internal documents properly reflect their actual position and intentions. Employees must understand the documents they create could be reviewed in the context of an investigation by a competition authority into suspected infringements of competition law. ${ }^{104}$

Courts should be aware of surrounding circumstances which undermine the credibility of originators' subjective purposes for entering into a reverse-payment settlement. The United States Supreme Court in Aspen Skiing Co v Aspen Highlands Skiing Corp rejected the purported purposes of Skiing Co discontinuing the all-Aspen ticket, saying they were "pretextual". ${ }^{105}$ In the context of a pharmaceutical patent settlement courts should be wary of the following:

(a) an agreement that restricts generic entry beyond patent expiry, without reasonable explanation;

(b) large settlement payments which exceed expected litigation costs;

(c) large settlement payments which exceed damages sought for potential patent infringement; and

(d) inconsistent clauses within a settlement.

99 Eisenberg and Crane, above n 19, at 243.

100 Bernadine Adkins "Paying for Delay and Patent Settlement Arrangements - The European Commission (At Last) Publishes the Lundbeck Decision" (29 January 2015) Gowling WLG <https://gowlingwlg.com>.

101 Matt Sherman, Peta Stevenson and Caroline Coops "ACCC v Pfizer and the Future of section 46" (2 March 2015) King \& Wood Mallesons <www.kwm.com>.

102 Downie, above n 17 , at 95 .

103 Pfizer, above n 85, at [351].

104 Adkins, above n 100.

105 Aspen Skiing Co v Aspen Highlands Skiing Corp 472 US 585 (1985) at 609-610; and Scott, above n 93, at 180. 
Since New Zealand does not offer patent extensions, a court should be more open to subjective intentions on the part of the originator who may consider the patent so valuable it is willing to pay a significant amount to avoid the slightest chance of invalidity.

\section{Effect or likely effect}

In determining whether the agreement has the effect or likely effect of substantially lessening competition, courts undertake a comparative analysis assessing the state of a hypothetical market with and without the relevant provision. ${ }^{106}$ This counterfactual analysis assesses the procompetitive and anticompetitive effects of a reverse-payment settlement and whether there is a net effect of substantially lessening competition. ${ }^{107}$ This test shares similarities with the "rule of reason" analysis the United States courts undertake. ${ }^{108}$ Glazebrook J in ANZCO Foods Waitara Ltd $v$ AFFCO New Zealand Ltd (ANZCO) identifies a list of factors which courts should take into account. ${ }^{109}$ These factors include barriers to entry and rate of foreclosure of the market. Dandy Power Equipment Pty Ltd $v$ Mercury Marine Pty Ltd requires a court to inquire about nature, extent and operation of the market. ${ }^{110}$

An agreement to restrict, limit or prevent the acquisition or supply of a particular drug will stifle competition by allowing an originator to maintain monopoly prices and restrict consumer choice. ${ }^{111}$ It is unclear how competitive a generic would be immediately on entry. Since doctors ultimately control consumer choice in the case of prescription drugs, changing prescribing patterns will follow with greater awareness and understanding of new medicines. Furthermore, consumer brand loyalty and fear of imperfect substitutability may extend an originator's ability to charge monopoly prices despite generic entry. ${ }^{112}$

The difficulty a court will face inquiring into the state of competition in a market with and without a reverse-payment settlement is the question of patent validity or infringement. Without a reversepayment settlement, litigation has two possible outcomes. First, the patent is invalid and a generic will enter the market free from restraint. Second, the patent will be valid and the generic will either enter the market at risk of infringing the patent or wait until the patent expires. Since settlement avoids patent litigation, undertaking an analysis using competing hypothetical markets is speculative. This is

106 ANZCO, above n 94, at [245].

107 Fisher \& Paykel Ltd v Commerce Commission [1990] 2 NZLR 731 (HC) at 740.

108 Actavis, above n 87, at 2237.

109 ANZCO, above n 94, at [244].

110 Dandy Power Equipment Pty Ltd v Mercury Marine Pty Ltd [1982] FCA 193, (1982) 44 ALR 173.

111 Bruzzone and Capozzi, above n 37, at 19.

112 Nicolas Gregory Mankiw Principles of Microeconomics (6th ed, South Western Cengage Learning, Canada, 2012) at 310 . 
especially so when the potential state of the market is dependent upon the original patent dispute. The Court in Actavis made clear the "rule of reason" analysis is not likely to require an assessment of the underlying patent action to decide whether a reverse-payment settlement is reasonable. ${ }^{113}$ This was because the majority equated a reverse-payment settlement with a weak infringement action. ${ }^{114}$ This is troubling when a settlement's "potential for genuine adverse effects on competition" is premised on the hypothetical that, had the patent been invalidated or not infringed, a large sum of revenues would have flowed to consumers in the form of lower drug prices. ${ }^{115}$

This article encourages New Zealand courts to depart from the above reasoning. A court should consider ex ante evidence of patent validity or infringement to determine the likely state of competition in the market. To establish a prima facie case challenging a reverse-payment settlement, the party alleging illegality should provide proof, other than the payment itself, that the likelihood of the patent's enforceability is low. ${ }^{116}$ This does not entail a separate decision; rather, it entails a consideration of the likely outcome. To avoid a "mini trial", courts should accept a lower burden of proof. For a court to continue an analysis under s 27 the plaintiff must prove a court would "likely" find the patent invalid or not infringed. Courts will undertake a more satisfactory analysis in determining whether a settlement harms consumers if they are willing to examine the merits of the patent validity or infringement action, rather than rely on deceptive alternatives such as reversepayments and estimations about intent to avoid litigation risks. Notably, the Supreme Court (now the High Court) in Phillip Morris (New Zealand) Ltd v Liggett \& Myers Tobacco Co (New Zealand) Ltd made clear an applicant need not establish a prima facie case on patent validity for an interim injunction. ${ }^{117}$ Expediency concerns associated with interim injunctions are not as prevalent in competition litigation and the anticompetitive effects of such conduct is the primary concern.

A preliminary assessment of the patent validity claim can address the concern of whether infringement or patent invalidity claims hold merit, or whether such settlements are a "thin camouflage" for improper collusion to delay competition. ${ }^{118}$ The majority in Actavis cautioned that settlements of weak patent infringement actions, that would have otherwise been decided in the generic's favour, will leave consumers worse off than they would have been had the parties continued with litigation. ${ }^{119}$ Agreements with exclusions beyond the scope of the patent (for example, future

113 Eisenberg and Crane, above n 19, at 234.

114 Actavis, above n 87, at 2237

115 Wang, above n 32, at 1255; and Actavis, above n 87, at 2234.

116 Daniel A Crane "Exit Payments in Settlement of Patent Infringement Lawsuits: Antitrust Rules and Economic Implications" (2002) 54 Fla L Rev 747 at 779-796.

117 Phillip Morris (New Zealand) Ltd v Liggett \& Myers Tobacco Co (New Zealand) Ltd [1977] 2 NZLR 35 (SC) at 38 .

118 Downie, above n 17, at 105.

119 Actavis, above n 87, at 2234-2235. 
production processes not covered by the patent) and disproportionate settlement amounts provide greater clarity that the generic's willingness to desist from market entry is based upon financial incentives rather than an objective assessment of the strength of the patent. ${ }^{120}$ The scope of the patent can only be accurately ascertained by an inquiry into the enforceability of such patent.

The Court in Actavis held anticompetitive effects are inferred if the amount of the reverse-payment exceeds the patent holder's anticipated litigation costs, absent some offsetting justification. ${ }^{121}$ For the Court, this was an indication of market power and obviated the need to inquire into the patent merits because the settlement exclusion period exceeded what was merited by the expected patent odds. ${ }^{122}$ Applying this standard seems contentious. First, side deals and separate clauses can obscure reversepayment amounts. For example, an excessive payment may reflect compensation for other services provided by the generic company. ${ }^{123}$ Second, defendants argue the payments are a legitimate and justified method of risk aversion. Third, when calculating damages from the reverse-payment amount, one can infer only a highly conservative floor, as the calculations do not consider the patent holder has anything to gain from the settlement. ${ }^{124}$

In 2015 the Commission released the Metal Roof Flashings Investigation Report which issued a warning to Consolidated Alloys that cl 8 of the Settlement Agreement breached s 27, as it had the purpose and likely effect of substantially lessening competition in the metal roof edge products market and the market for soft-edge flashing products, during a post-patent period. ${ }^{125}$ Clause 8 restricted Edging Systems Ltd from introducing any new soft-edge flashing products and applied beyond patent expiration. ${ }^{126}$ In assessing likely effect, the Commission considered the impact entry of a competitor would have on price and sales. This may be a difficult inquiry to undertake in the context of pharmaceuticals, as competition is sparse for an originator where a generic is yet to enter the market. Where an agreement restricts entry beyond the post-patent period a separate analysis considering competition in the market will need to be undertaken. In such circumstances, a settlement will go beyond legitimate conduct to protect a patent right and will have the effect of substantially lessening competition in the market.

120 Adkins, above n 100.

121 Actavis, above n 87, at 2237.

122 McGuire and others, above n 62, at 1585.

123 Eisenberg and Crane, above n 19, at 240.

124 McGuire and others, above n 62, at 1587.

125 Commerce Commission, above n 43, at 13.

126 At 19. 
Justice Glazebrook suggests if the firm affected is a small firm then there is unlikely to be substantial lessening of competition. ${ }^{127}$ Her Honour took issue with the fact that the encumbrance in ANZCO only affected a small competitor in a small part of the market. ${ }^{128}$ She noted s 27 is not concerned with the fate of individual competitors. ${ }^{129}$ While this holds truth, one of the ways in which parties to an agreement can substantially lessen competition is by practices which injure competitors and thereby injure the competitive process itself. ${ }^{130}$ Some firms are mavericks which have a disproportionate effect on the market. ${ }^{131}$ In a cosy oligopoly, entry of a maverick can shake things up and an agreement to stop a maverick entering can substantially lessen competition, irrespective of its small size. ${ }^{132}$ A generic is comparable to a maverick. Entry of such can have enormous effects by reducing drug price, on average 85 per cent below the brand price, and by increasing consumer choice. ${ }^{133}$

\section{Section 36}

The other pivotal restrictive trade practices provision is $\mathrm{s} 36$. There is a particular need for robust monopolisation provisions in small market economies such as New Zealand, where high levels of concentration exist. ${ }^{134}$

McHugh J in Boral Besser Masonry Ltd v Australian Competition and Consumer Commission described the approach to $\mathrm{s} 36$ as a sequential analysis: ${ }^{135}$

[262] First, the court must identify the relevant market in which the conduct occurred. Second, the court must determine whether the alleged offender had a substantial degree of market power. Third, the court must determine whether the alleged offender has taken advantage of that market power. Finally, the alleged offender must have engaged in the conduct for one of the proscribed purposes.

The courts' application of s 36 has attracted considerable criticism from academics. Most criticism circulated in response to the Supreme Court's interpretation in Commerce Commission v Telecom

127 ANZCO, above n 94, at [248].

128 Scott, above n 93, at 190.

129 ANZCO, above n 94, at [248].

130 Scott, above n 93, at 190.

131 Jonathan B Baker "Mavericks, Mergers and Exclusion: Proving Coordinated Effects Under the Antitrust Laws" (2002) 77 NYU L Rev 135 at 140

132 At 140

133 Carrier, above n 26, at 479.

134 Michal S Gal "The Effects of Smallness and Remoteness on Competition Law - The Case of New Zealand" (2007) 14 CCLJ 292 at 295.

135 Boral Besser Masonry Ltd v Australian Competition and Consumer Commission [2003] HCA 5, (2003) 215 CLR 374. 
Corporation of New Zealand Ltd (0867) of s 36 and "taking advantage" in light of alternative tests. ${ }^{136}$ It is beyond the scope of this article to discuss whether the counterfactual test is a manifestation of alternate tests or whether these tests exist independently. This Part will assess the likely application of s 36 to reverse-payment settlements and whether the comparative exercise, endorsed by the Supreme Court, provides an adequate framework for analysis. ${ }^{137}$

\section{Substantial market power}

In changing the threshold test from "dominant position" to "substantial degree of power in a market", policy makers intended to broaden s 36's applicability not only to monopolists but also to the main players in an oligopoly. ${ }^{138}$ The absence of constraint is the essence of market power. ${ }^{139}$ While market power commonly refers to influence upon market price, conduct directed at excluding competition is another indicator. ${ }^{140}$ A dominant share of the market infers the existence of monopoly power. ${ }^{141}$ Where it is not possible or rational for new entrants to participate in the market, a firm can have market power. ${ }^{142}$

An originator holds a legal monopoly over a particular drug for the patent term. No other pharmaceutical company can manufacture and supply a drug in breach of the originator's patent. In the pharmaceutical industry, substitutes are rarely available and patients requiring a particular drug are not in a position to choose an alternative or refuse treatment. Arguably, this power has been "thrust upon" them in an effort to protect investment in research and development. ${ }^{143}$ To some it may seem unjust to attach liability purely on this basis. Exclusive rights granted by a patent usually equates with market power and it would be unusual for a judge to find that an originator company lost substantial market power before patent expiry. Despite the above, Flick J in Pfizer concluded Pfizer's market power gradually decreased as a result of the preparatory activities competitors undertook in

136 Scott, above n 93; Queensland Wire Industries Pty Ltd v The Broken Hill Pty Co Ltd (1989) 167 CLR 177 (HCA) [QWI] at [195]; Melway Publishing Pty Ltd v Robert Hicks Ltd [2001] HCA 13, (2001) 205 CLR 1; and Andrew Gavil "Imagining a Counterfactual Section 36: Rebalancing New Zealand's Competition Law Framework" (2015) 46 VUWLR 1043.

137 In November 2017, s 46 of Australia's Consumer and Competition Amendment Act 2017 (equivalent of New Zealand's s 36) introduced a "substantial lessening of competition" test. Thus, the "substantial lessening of competition" analysis under s 27 in this article could be a "look into the future" for how it may play out under a s 46 analysis in Australia (and in New Zealand if it were to follow suit).

138 Hampton and Scott, above n 70, at 212.

139 Boral, above n 135, at [121].

140 Hampton and Scott, above n 70, at 214-216.

$141 Q W I$, above n 136, at 189.

142 At 189.

143 United States v Aluminium Company of America 148 F 2d 416 (2nd Cir 1945) at 429. 
anticipation of patent expiration. ${ }^{144}$ Accordingly, his Honour concluded that by January 2012, Pfizer's market power was no longer "substantial". ${ }^{145}$ Pfizer's patent expired in May 2012. ${ }^{146}$ Pfizer makes clear market power is not substantial unless it can be sustained over a "reasonable period of time". ${ }^{147}$ The Court blurs the distinction between competitive restraints which reduce substantial market power, and constraints which result in a loss of substantial market power. PHARMAC's strategy incentivises generics to enter the market by "waiting out" patents and funding the generic substitutes. ${ }^{148}$ Since New Zealand's patent scheme does not offer extensions, a generic making preparations to introduce a bioequivalent drug will gain access to the market immediately on patent expiry. In such circumstances, an originator's market power prior to patent expiry, may diminish as the entry of a generic becomes unavoidable.

The reasoning in Pfizer is unsatisfactory, stands in stark contrast to similar cases overseas and is unlikely to apply in the New Zealand context. First, the decision is at odds with how pharmaceutical monopolies operate. A patentee has the exclusive right to make, use, sell or otherwise deal in the invention in New Zealand until patent expiration. ${ }^{149}$ Second, while competition is inevitable it is difficult to see how the extent of preparations any generic competitor pursued could have sufficiently diminished the market power of an originator below "substantial", without infringing exclusive rights of the patentee. Third, an originator will not lose all its market power even on patent expiration. ${ }^{150}$ It is common for consumers to remain loyal to the brand, often out of fear the generic's chemical components will be inferior. ${ }^{151}$ For example, the patent on fluoxetine, a widely used antidepressant, expired in $2001 .{ }^{152}$ A consumer has the choice between the brand drug, Prozac, and a variety of generic versions. ${ }^{153}$ Despite this, Prozac sells for almost three times the price of generic fluoxetine. ${ }^{154}$ The maintenance of this price differential can be attributed to consumers being dubious about the substitutability of the two pills. ${ }^{155}$ Fourth, in AstraZeneca v European Commission it was not until

144 Pfizer, above n 85, at [286].

145 At [287].

146 At [4].

147 At [42].

148 Researched Medicines Industry Association of New Zealand Inc, above n 9, at 4.

149 Patents Act, s 18.

150 Mankiw, above n 112, at 310 .

151 At 310

152 At 310

153 At 310 .

154 At 310

155 At 310 
AstraZeneca's market share dropped to between 61-75 per cent in each relevant country after generic entry that it lost dominance. ${ }^{156}$ In the United Kingdom, AstraZeneca's market share dropped from 100 per cent to 64 per cent between 1991 and $1999 .{ }^{157}$ AstraZeneca also benefited significantly from its position as incumbent, and evidence of strong inertia in doctors' prescribing patterns and brand loyalty contributed to its continued dominance after competitor entry. ${ }^{158}$ These are crucial considerations for a New Zealand court, especially in a highly concentrated small market economy.

A New Zealand court should depart from Flick J's reasoning in Pfizer and presume an originator will possess market power up until generic entry and/or patent expiration. This event marks the logical transition of the originator having substantial market power to something less substantial. In the pharmaceutical context, Bain argues patents act as long-term barriers to entry, where an originator can earn above normal profits without the threat of entry. ${ }^{159}$ Furthermore, the market share of an originator is likely to be close to 100 per cent. Consistent with Miller J's reasoning in Commerce Commission v New Zealand Bus Ltd (No 2), where an originator patentee is able to persistently earn high profits over the term of its 20 year patent, this indicates substantial market power. ${ }^{160}$ In Actavis the Court indicated the threshold for proving market power would be a very low one, stating "[t]he size of the payment from a branded drug manufacturer to a [prospective] generic is a strong indicator of ... power." ${ }^{161}$ A pharmaceutical monopolist facing threat of generic entry on the patent expiration, will not necessarily lose that market power once the uncertainty arises. ${ }^{162}$ Absent an "at risk" early generic entry or licence prior to patent expiry, an originator patentee in a one-product market will preserve substantial market power until patent expiry. Sections 18 and 140 of the Patents Act support this in defining what it means to infringe a patent as doing anything a patentee has exclusive right to do. These rights include making, hiring, selling or disposing of the product, or offering to do so, or using or importing the product or keeping the product for the purpose of doing any of the prior things. ${ }^{163}$ Pharmacies wishing to supply a patent-protected medicine must go through the patentee.

Timing will be a crucial consideration for the courts, including whether a generic has already obtained a listing and the life of the patent remaining. Where a drug becomes listed on the Pharmaceutical Schedule, evidence of loss of market share upon generic entry can support an

156 Downie, above n 17 , at 103.

157 At 103

158 At 103.

159 Joe Bain Barriers to New Competition: Their Character and Consequences in Manufacturing Industries (Harvard University Press, Cambridge, 1956) at 3.

160 Commerce Commission v New Zealand Bus Ltd (No 2) (2006) 3 NZCCLR 854 (HC) at [51].

161 Actavis, above n 87, at 2236.

162 Downie, above n 17, at 89 .

163 Patents Act, s 18. 
argument that the originator has lost substantial market power before patent expiry. It would be unusual for a generic to attempt to enter the market or challenge patent validity close to patent expiration. It is more likely to challenge an originator's patent and attempt market entry early or towards the midpoint of the 20-year term. During this time, an originator is more likely to have substantial market power.

It is highly likely an originator pharmaceutical during the term of its patent has substantial market power. Although, this in itself is not illegal, a firm must take advantage of this power for one of the proscribed purposes.

\section{Taking advantage}

To breach s 36 a firm with substantial market power must take advantage of that power. First, the conduct at issue must be characterised. ${ }^{164}$ Second, a comparative exercise test must be undertaken, as confirmed by the Supreme Court in 0867. It must be shown, on the balance of probabilities, that the firm in question would not have acted as it did in a workably competitive market; that is, if it had not been dominant. This is a manifestation of the conventional counterfactual test from Queensland Wire Industries Pty Ltd v The Broken Hill Pty Co Ltd. ${ }^{165}$

The characterisation of the relevant conduct in reverse-payment settlements will be pivotal. In Melway Publishing Pty Ltdv Robert Hicks Ltd the High Court of Australia preferred Heerey J's dissent in the Full Federal Court and characterised Melway's conduct as an attempt to maintain its distribution system, as opposed to refusal to supply. ${ }^{166}$ This characterisation enabled the majority to allow the appeal and conclude Melway had not taken advantage of its market power. ${ }^{167}$ In a reverse-payment settlement context, conduct may be characterised as paying a generic drug company to delay entry into the market or reaching a settlement with a generic drug company to avoid the risks of litigation. This characterisation will guide the following analysis.

The originator pharmaceutical company must lose substantial market power and be placed in a hypothetical competitive market. Then, it must be considered whether they would engage in the same behaviour. In the context of reverse-payment settlements, a counterfactual analysis is difficult to undertake. Stripping the originator of market power would involve removing its patent and the accompanying monopoly. Without its patent, patent litigation would never have eventuated and the opportunity to settle is nil. The logical conclusion is that without substantial market power the originators would not have even had the opportunity to enter into a reverse-payment settlement. Furthermore, the rationale for a reverse-payment settlement disappears, leaving a naked market

164 Commerce Commission v Telecom Corporation of New Zealand Ltd [2010] NZSC 111, [2011] 1 NZLR 577 [0867 case] at [8].

$165 Q W I$, above n 136

166 Melway, above n 136, at [62].

167 At [86]. 
sharing or capacity withholding agreement. ${ }^{168}$ On a literal application of the counterfactual test, an originator would be taking advantage of its substantial market power since it would not have acted as it did if it were in a competitive market. Asking whether the originator would have acted in the same way in a competitive environment requires constructing a factually inaccurate and artificial situation. A way around this issue would be to introduce competitors, all with their own patents and slightly different products which nonetheless compete.

A mere settlement is unlikely to satisfy the take advantage test, as this conduct may have been undertaken in a competitive market. ${ }^{169}$ Any presumption of illegality pertains to unnecessary harshness on settlement parties and would "unduly chill patent infringement settlements". ${ }^{170}$ The Court in 0867 adopted the legitimate business rationale test as part of the comparative exercise. ${ }^{171}$ The High Court of Australia in Boral Besser Masonry Ltd originally proposed the test. ${ }^{172}$ If a firm gives legitimate reasons for its conduct, this suggests a firm without substantial market power would engage in the same conduct in a competitive market. The Privy Council in Carter Holt Harvey Building Products Group Ltd v Commerce Commission also approved the legitimate business rationale. ${ }^{173}$

The requisite taking advantage may be the originator's ability to pay a large sum to the generic to delay entry which is connected to its financial strength and monopoly in the relevant drug market. ${ }^{174}$ Financial strength does not necessarily equate to market power. ${ }^{175}$ However, where the originator's financial strength is intimately linked with a patent monopoly, its ability to persuade the generic to discontinue litigation and settle is otherwise related to it taking advantage of its substantial market power. ${ }^{176}$ It is only by virtue of its control of the market and absence of other manufacturers that an originator can financially afford a reverse-payment settlement with a generic. Otherwise, an originator earning less than monopoly profits will not recoup the large settlement sum. In a market with existing

168 This situation would almost certainly breach the revised s 30 of the Commerce Act.

169 Downie, above n 17, at 110.

170 Daniel Crane "Ease Over Accuracy in Assessing Patent Settlements: A Response to Herbert Hovenkamp, Mark Janis, and Mark A Lemley Anticompetitive Settlement of Intellectual Property Disputes" (2003) 88 Minn L Rev 698 at 709.

1710867 case, above n 164, at [25].

172 Boral, above n 135, at [170].

173 Carter Holt Harvey Building Products Group Ltdv Commerce Commission [2004] UKPC 37, [2006] 1 NZLR 145 at [54].

174 Downie, above n 17, at 110.

175 At 110 .

176 At 110. 
competitors, an originator has no incentive to preserve its monopoly and keep other generics out of the market.

Evidence of the financial size of the settlement will either be an accurate representation of potential damages awarded and saved litigation costs or it will point towards an arbitrary and exaggerated reverse-payment. Evidence of the latter will undermine any suggestion the settlement was a legitimate business decision and a viable one for a firm without market power. Conversely, a court should be aware of a patent holder's extreme risk-averse activities, which may also explain a disproportionate settlement.

There are legitimate reasons for entering into a reverse-payment settlement unrelated to a defendant's market power. As the majority recognised in Actavis, a reverse-payment may be compensation for other services the generic company performed. ${ }^{177}$ These services might include distributing the patented product or contributing to the development of a market for that product. ${ }^{178}$ This will require a court to examine other clauses in the agreement and look for a rationale behind an exaggerated payment. Another justification is where an originator and generic wish to avoid scrutiny triggered by a reverse-payment all together. ${ }^{179}$ In such a case, they reverse the apparent direction of payment by having a generic promise to pay the patentee for the right to be a distributor. ${ }^{180}$ This is similar to sharing revenues as a royalty. There is both the absence of a reverse-payment and the fact of early generic entry, which should easily satisfy the Actavis rule of reason approach. Similarly, a settlement containing an exclusive distributor provision is unlikely to amount to taking advantage of the originator's market power, as such arrangements are regularly entered into in competitive markets. ${ }^{181}$ A settlement which largely matches expected litigation costs and merely prevents entry until patent expiration, is conduct a firm in a competitive market would have undertaken. The main difference is the effect of such conduct.

A critical flaw with the counterfactual test is that an originator with substantial market power can pass the test even if the effect of its behaviour when carried out by a company with market power, damages the competitive process. ${ }^{182}$ The test ignores the fact that consequences of the same conduct practised by a firm with market power will be different when compared to a firm without it. The prohibition ought to cover conduct with the purpose or effect of harming the competitive process. ${ }^{183}$

177 Actavis, above n 87, at 2236.

178 Eisenberg and Crane, above n 19, at 240

179 At 240

180 At 240

181 Downie, above n 17, at 110.

182 Donal Curtin "Abuse of market power: the end of 'make-believe' analysis?" (paper presented to the New Zealand Association of Economists Conference, Auckland, 30 June 2016) at 6.

183 At 8 . 
The analysis will echo that of s 27 where the effects of such settlements are to be considered. This includes a plaintiff demonstrating that the settlement amount or provisions are unjustified and the potential enforceability of the patent is low.

\section{Proscribed purpose}

Demonstrating an originator took advantage of its substantial market power for one of the proscribed purposes in s 36 is likely to encounter similar obstacles. An exclusive distributer arrangement will likely fall outside this test where parties can demonstrate the exclusivity arrangements foster efficiencies and/or build commercial relationships between parties. ${ }^{184}$

Where a reverse-payment settlement delays generic entry into the market beyond the term of the patent, this may amount to conduct designed to prevent a generic engaging in competitive conduct in that market. This satisfies two of the three proscribed purposes in s 36 . Where payments exceed the value of the patent, a court may also infer an anticompetitive purpose. ${ }^{185}$

\section{CONCLUSION}

Absent empirical evidence as to their frequency or content in New Zealand, anticipating how New Zealand competition law will treat reverse-payment settlements is highly speculative. Given the diverse nature of such agreements, the Commission will have the full arsenal of Commerce Act pt II restrictive trade provisions at its disposal in testing the legality of reverse-payment settlements in New Zealand.

This article has reached the following conclusions:

(1) The conventional SSNIP test used by New Zealand courts to define the market is of limited utility in the unique pharmaceutical context.

(2) Assessing anticompetitive effects of a reverse-payment settlement, under s 27, is impossible without a court inquiring into the original patent validity or infringement dispute.

(3) A reverse-payment settlement will only infringe s 27 where the likelihood of success in a patent validity or infringement action is low and/or where the settlement restricts entry beyond the scope of the patent.

(4) Section 36 will not catch an originator who enters a settlement preventing generic entry until patent expiry, despite it having anticompetitive effects on the market. This is fundamentally flawed and gives weight to the argument an "effects-based" approach should replace the counterfactual inquiry.

Parties should be required to lodge reverse-payment settlements with the Commission. This would take a change in statute. This recommendation mirrors that of Australia's Productivity Commission,

184 Downie, above n 17, at 111.

185 Actavis, above n 87, at 2237. 
which acknowledges that the lack of settlements and evidence are a reflection of poor monitoring arrangements, rather than absence of such activity. A monitoring arrangement would deter and detect such behaviour. 
